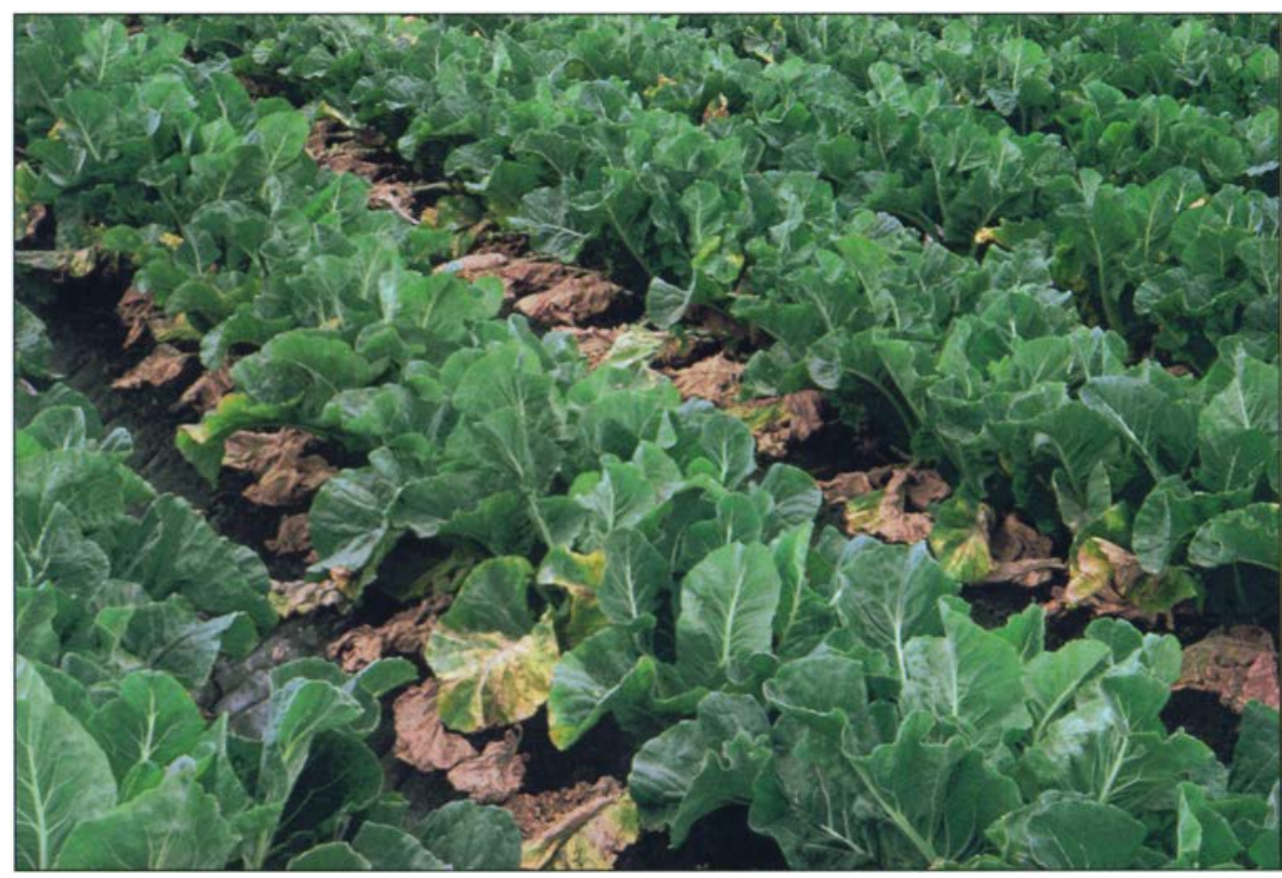

Symptoms of cauliflower Verticillium wilt, showing extensive leaf yellowing and senescing.

\section{Broccoli residues can control Verticillium wilt of cauliflower}

\author{
Steven T. Koike $\square$ Krishna V. Subbarao
}

Verticillium wilt, a damaging disease of cauliflower, was successfully managed in a multiple-year field study by incorporating broccoll residues into infested soil. In a study conducted from 1993 to 1995 in the Salinas Valley, cauliflower disease incidence and severity were consistently and significantly reduced in the broccoli residue plots when compared with no broccoli. The commercial standard plots fumigated with methyl bromide + chloropicrin had the lowest disease incidence and severity. In both years of our tarping study, Verticillium wilt severity was lowest in the metham sodium treatment. The cauliflower-Verticillium host-pathogen system therefore can act as a model for controlling soll-borne diseases without the use of synthetic chemicals.
Cauliflower is one of the many important vegetable crops grown in California. Statewide in 1997 there were 37,200 acres with a gross value of more than $\$ 168$ million. The coastal counties are particularly prominent cauliflower production areas and a 6-county coastal region (Monterey, San Benito, San Luis Obispo, Santa Barbara, Santa Cruz and Ventura) produced approximately $84 \%$ of the acreage and $86 \%$ of the value of the state's crop. Monterey County is the largest producer of this crop, worth $\$ 117$ million in 1997 on 19,475 acres. Imperial County is the other significant California cauliflower production area. This south desert region produced 3,460 acres in 1997. In Monterey County's Salinas Valley where the crop is grown virtually year-round, cauliflower is subject to several soil-borne diseases, such as wire stem caused by Rhizoctonia solani, black leg caused by Phoma lingam, clubroot caused by Plasmo-

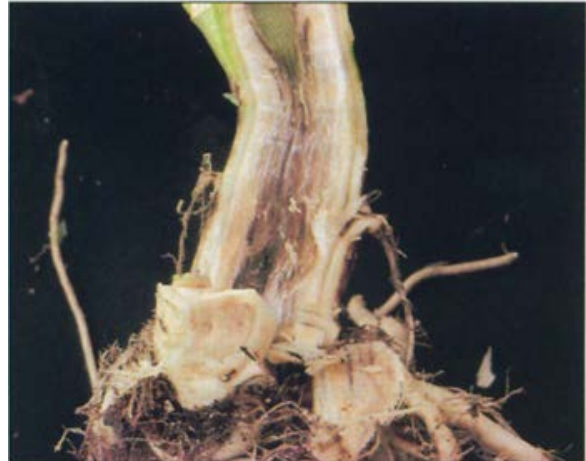

A Symptoms of cauliflower Verticillium wilt, showing typlcal vascular discoloration.

\section{$\nabla$ Photomicrograph of the survival propagule (microsclerotium) of Verticil- IIum dahllae.}

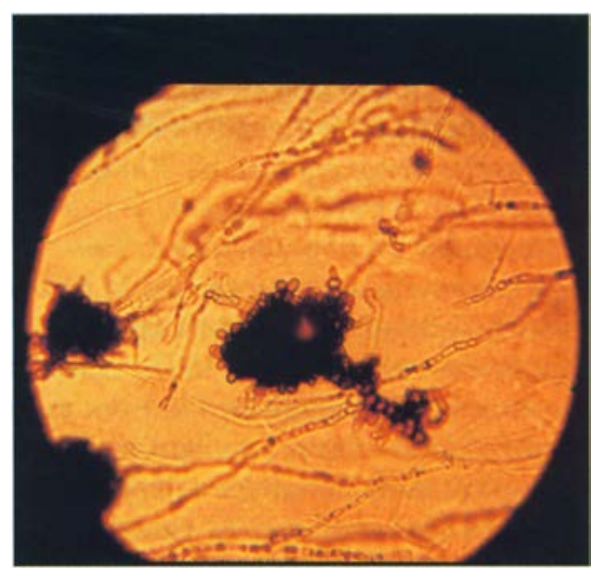

diophora brassicae and root rot caused by Phytophthora species. Cauliflower is also a host to cyst nematodes (Heterodera schachtii and H. cruciferae). However, the impact of these diseases and nematodes varies and usually does not cause consistent, significant economic losses.

\section{New cauliflower problem}

Beginning in the early 1990s, numerous cauliflower plantings in the Salinas Valley began to show symptoms of a previously undescribed disease. Our research group identified this new disease as Verticillium wilt caused by Verticillium dahliae. This was the first report of cauliflower as a host of this soil-borne pathogen (Koike et al. 1994). Disease symptoms, which begin when the cauliflower matures and develops flower heads, appear as the yellowing of older, lower leaves. As disease progresses, the yellowed leaves become brown, dry, and even- 
tually fall off the plant. During warm daytime periods, the entire leaf canopy wilts. Affected plants are stunted and produce cauliflower heads that are small and of poor quality. The inner vascular tissues of stems and roots have extensive, distinctive, black streaking.

\section{Disease control alternatives}

Controlling Verticillium wilt of cauliflower, like Verticillium diseases on most other crops, is difficult. The fungus produces survival structures (microsclerotia) that can persist in the soil for many years. The ability of this fungus to survive for long periods, in combination with a very broad host range, makes crop rotation impractical. Resistant cauliflower cultivars are not available and soil fumigants such as methyl bromide and chloropicrin provide some control but are too expensive to use for cauliflower production and may not even be available in the future for agricultural use. Therefore, there is an urgent need to discover alternative soil-borne pathogen controls that are effective, affordable and not harmful to the environment.

During our initial'work on cauliflower Verticillium wilt, we noticed that although broccoli is closely related to cauliflower, broccoli crops were never infected with $V$. dahliae even when planted in the same highly infested fields. When greenhousegrown broccoli was inoculated with $V$. dahliae isolated from cauliflower, the broccoli did not develop Verticillium wilt and microsclerotia were not observed on broccoli roots. In addition, researchers have been interested in the possible fungicidal properties of chemical substances present in many cruciferous crops (Brown and Morra 1997; Mayton et al. 1996). Substances such as glucosinolates and other toxic volatile compounds, released during crop residue breakdown, could possibly be exploited to control soil-borne pathogens or otherwise suppress soilborne diseases (Gamliel and Stapleton 1993; Mojtahedi et al. 1991). The quality and amount of glucosinolates differ among various crucifer plants. Because of broccoli's apparent status as a nonhost of $V$. dahliae and the known fungicidal properties of the particular glucosinolates in this plant (Harborne and Baxter 1993), we conducted a series of studies to investigate the usefulness of broccoli residues in suppressing Verticillium wilt of cauliflower.

\section{Effects of broccoli in the lab}

In a replicated laboratory study, we evaluated the effect of broccoli residue under various temperatures. After placing 25 grams of $V$. dahliae-infested soil into plastic bottles, we mixed in the following amendments: fresh broccoli ( $8 \% \mathrm{wt} / \mathrm{wt}$ of broccoli/soil), dry broccoli (weight equivalent to the fresh broccoli treatment), and no broccoli. The amount of added broccoli corresponded to the fresh weight of broccoli residue remaining after a typical commercial broccoli harvest in the Salinas Valley (25 tons/acre). The soil and broccoli combinations were incubated at $10,15,20,25,30$ and $35^{\circ} \mathrm{C}$ for a period of 45 days, then evaluated for microsclerotia survival.

For each temperature in the experiment, both dry and fresh broccoli significantly reduced the numbers of living microsclerotia (fig. 1). Fresh broccoli reduced microsclerotia survival more than dry broccoli at all temperatures below $86^{\circ} \mathrm{F}\left(30^{\circ} \mathrm{C}\right)$; above $77^{\circ} \mathrm{F}\left(25^{\circ} \mathrm{C}\right)$, the pathogen was virtually eliminated by the fresh broccoli treatment (Subbarao and Hubbard 1996).

\section{A 2-year field study confirms}

We conducted a 2-year study (19941995) in Verticillium-infested field plots located in the Salinas Valley. Each year, the main treatments for the randomized, replicated experiment were broccoli residue incorporated into plots, no residue in the plots, and a fumigated control $(50 \%$ methyl bromide $+50 \%$ chloropicrin at $370 \mathrm{lb} /$ acre). These treatments were also tested under different irrigation methods (furrow and drip) and rates (deficit, moderate and excessive). To obtain the residue for the treatments, the broccoli was grown in the broccolidesignated plots to maturity, heads were removed to simulate commercial harvesting, and the remaining residue was incorporated at a rate approximately equal to 25 tons/acre. After residue decomposed for 3 weeks which corresponds to a common fallow period between crops - plots were prepared for planting, cauliflower was transplanted into all plots and grown to maturity.

We evaluated microsclerotia populations in soil at periodic intervals and assessed the percent of Verticillium wilt incidence and severity for the subsequent cauliflower crops. For disease severity, we cut into the stem longitudinally and used a rating scale of 0 to 5 to assess vascular discoloration in the stem $(0=$ no vascular discoloration; 1 $=1-10 \% ; 2=11-30 \% ; 3=31-50 \% ; 4=$ $51-75 \% ; 5=76-100 \%)$.

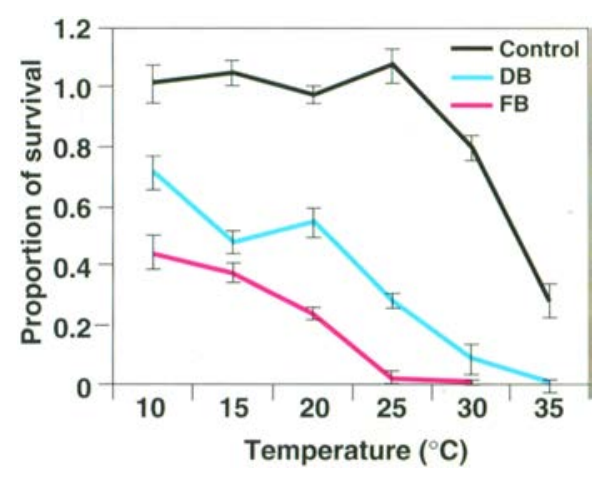

Fig. 1. Percent of surviving V. dahliae microsclerotia in naturally infested solls amended with dry (DB) or fresh (FB) broccoll residue or left unamended (Control) and incubated in the laboratory at different temperatures for $\mathbf{4 5}$ days.

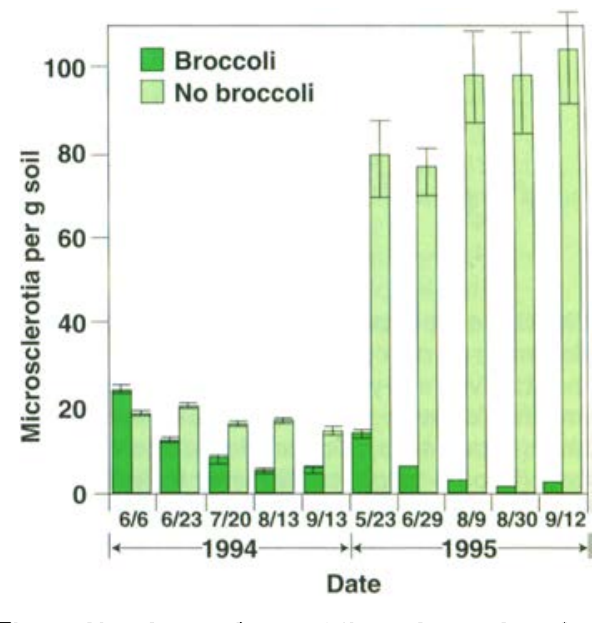

Fig. 2. Numbers of $V$. dahliae microsclerotia per gram of soll, during a 2-year field experiment, from plots that were treated with broccoll residue or left unamended. Pathogen populations were virtually identical in all plots when the study was initiated. 
Over the 2-year period, we observed a significant decline in the number of microsclerotia in soil treated with broccoli residue (fig. 2). In contrast, soil not treated with the broccoli residue experienced a fivefold increase in the number of microsclerotia. Irrigation methods (furrow vs. drip) had no consistent, significant effect on the microsclerotial populations between the two treatments. Likewise, differing amounts of irrigation water (deficit, moderate and excessive volumes) generally did not significantly influence pathogen numbers in broccoli or non-broccoli plots.

When we assessed the percent of Verticillium wilt infection and severity during this 2-year study, we generally did not see significant differences between the furrow and subsurface drip irrigation plots (data not shown). However, Verticillium wilt incidence was usually higher in the excessive irrigation regime when compared to moderate and deficit watering treatments. For both years of the study, disease incidence and severity were consistently and significantly reduced

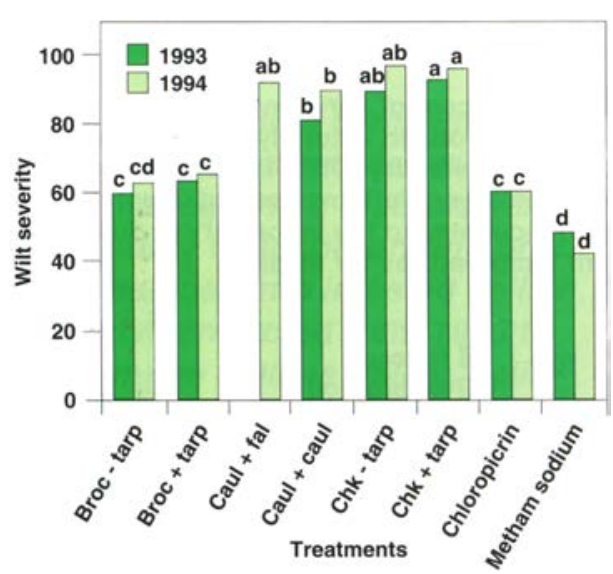

Fig. 3. Verticillium wilt severity of caullflower grown in plots having various treatments over a 2-year period. Treatments are the following: broccoli residue without tarp (Broc - tarp); broccoli residue with tarp (Broc + tarp); caullilower followed by fallow (Caul + fal); two consecutive cauliflower plantings (Caul + caul); untreated control without tarp (Chk - tarp); untreated control with tarp (Chk + tarp); chloropicrin (485 lb/acre); metham sodium (60 gal/ acre). For disease severity, the rating scale of 0 to 5 was used to assess vascular discoloration in the stem xylem $(0=$ no vascular discoloration; $1=1-10 \% ; 2=11-$ $30 \% ; 3=31-50 \% ; 4=51-75 \% ; 5=76-100 \%$ ). in the broccoli residue plots when compared with no broccoli. Not surprisingly, the commercial standard plots fumigated with methyl bromide + chloropicrin (the control plots with no $V$. dahliae microsclerotia) had the lowest disease incidence and severity under all irrigation regimes.

\section{Tarping doesn't affect activity}

Fumigants are usually more effective in controlling soil-borne pathogens if the treated soil is covered with plastic tarps after application. We were interested in measuring the effectiveness of broccoli residue under tarped and non-tarped conditions. We established another 2-year study (1993-1994) using a randomized, replicated experiment in a field naturally infested with $V$. dahliae. Treatments for the 2 years were the following: broccoli residue (equivalent of 25 tons/ acre) with tarp; broccoli residue ( 25 tons/acre) without tarp; untreated control with tarp; untreated control without tarp; two consecutive cauliflower plantings; cauliflower followed by fallow; metham sodium (Vapam) (60 gal/acre); chloropicrin (485 lb/ acre). Tarps were removed after 2 weeks, cauliflower was planted into all plots, and Verticillium wilt severity was then evaluated in all plots near cauliflower maturity.

In both years of this study, we found that Verticillium wilt severity was lowest in the metham sodium treatment (fig. 3). Both broccoli treatments (tarped and non-tarped) were comparable to the chloropicrin fumigation treatment. Most interestingly, the tarped and non-tarped broccoli plots had equivalent disease severities, suggesting that the effectiveness of broccoli residues was not dependent on volatile substances released by the decaying material. Untreated controls (both tarped and non-tarped) had the highest disease severity for both years (Subbarao et al. 1999).

\section{Novel method of disease control}

In the laboratory study, fresh broccoli residue demonstrated significant activity in reducing microsclerotia viability of $V$. dahliae over a broad temperature range. The material was most effective at temperatures greater than $77^{\circ} \mathrm{F}$. When we applied this finding to commercial agricultural settings, we found that broccoli residue consistently resulted in reduced populations of microsclerotia and decreased disease incidence and severity. Yield data showed that cauliflower plants grown in broccoli-amended plots produced greater numbers of larger, marketable heads compared to untreated plots. Irrigation methods and rates did not account for the observed differences in $V$. dahliae populations in broccoli and non-broccoli plots. Of particular interest was the finding that the broccoli residue effects were unaffected by the presence or absence of plastic tarps. If growers are able to control disease by using broccoli residues without tarps, they would have the added benefit of not being concerned with obtaining or disposing of the plastic tarps.

Because of the environmental, regulatory, economic and political concerns of using synthetic, highly toxic agrichemicals, agricultural industry and research teams are attempting to find viable alternatives to these materials. Such alternatives must be effective, economical and not harmful to the environment. The use of broccoli residue for controlling soil-borne pathogens perhaps offers a novel means of controlling such pests. Our experiments using broccoli residue have demonstrated its effectiveness in significantly reducing populations of $V$. dahliae. If sufficient volumes of broccoli residue are used as a regular component of crop rotation cycles, this suppressive activity may be even further heightened.

This technique is economical because the broccoli effect does not require the harvestable heads; hence the crop generates revenue and the remaining residues contribute to disease control. This utility of having the crop harvested is an important feature of this method, as other disease-suppressing crops, such as cover crops, are not harvested and therefore do not generate revenue for the grower. Plastic tarps, another economic factor, add significantly to soil treatment costs and are not necessary for the broccoli amendment effects. Finally, broccoli residues 
are natural materials and pose no threat to the environment, surrounding crops, wildlife or people.

The use of broccoli residue in this way is particularly well-suited and available to vegetable growers in the Salinas Valley because of the extensive plantings already grown in this valley. In 1997 , over 56,000 acres were produced, having a value of $\$ 225$ million. This technique can be exploited by large and small acreage growers as well as by both conventional and organic producers.

The usefulness of broccoli residue as an integrated pest control option is further highlighted by its potential versatility in managing multiple target pests. We, as well as industry groups, are already investigating the role broccoli residue might play in controlling soil-borne diseases of other crops, such as lettuce, pepper and strawberry; and we are investigating its effect on pathogens other than Verticillium, such as Sclerotinia. In addition, growers have observed for many years that when left-over broccoli residues from processing plants were incorporated into fields, those locations had reduced weed growth in subsequent seasons. Broccoli residue is most likely suppressing weeds and perhaps other types of pests as well. In summary, broccoli residue incorporation, as a disease control practice, is an innovative means of managing Verticillium wilt of cauliflower that is effective, economically feasible and non-polluting to the environment.

S.T. Koike is Plant Pathology Farm Advisor, Monterey and Santa Cruz counties; and K.V. Subbarao is Associate Plant Pathologist/Associate Specialist in Cooperative Extension, Department of Plant Pathology, UC Davis and located at U.S. Agricultural Research Station, Salinas. The authors thank J. Aragon, S. Bassi, A. Caminay, S. Dacuyan, J.E. DeVay, K. Fowler, T.G. Gonzales, J.C. Hubbard, D. Lindsay, P. Niday, E.D. Oakes, J. Manassero, M. Mulanax, R. Miller, S. Ray, B. Taylor, J. Taylor, M. Vidauri, J. Wakeman, C.-L. Xiao, and California cauliflower growers. We thank Tri-Cal for applying the fumigant materials. This research was partially supported by grants

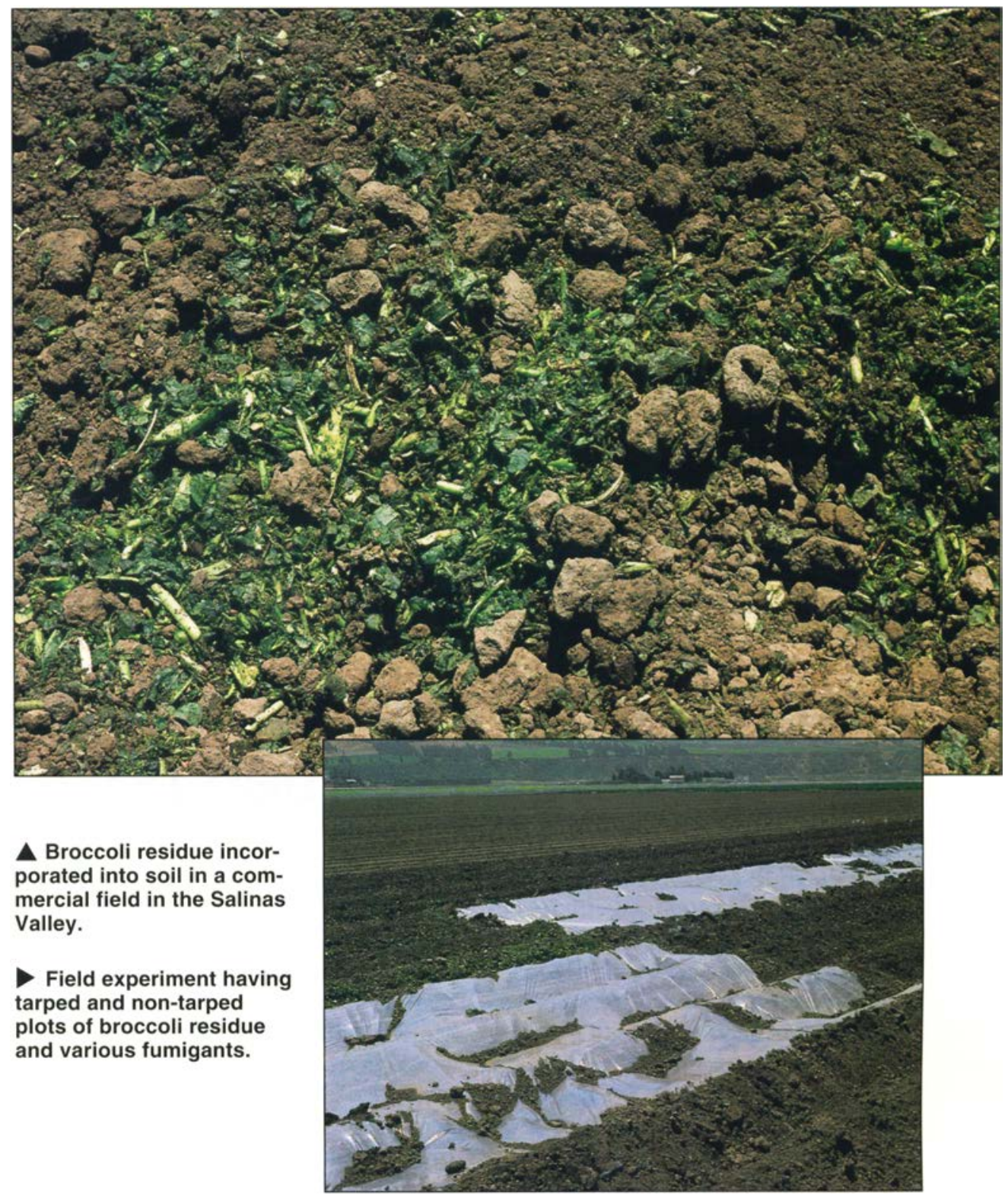

from the UC DANR Special Grants Program, UC IPM Program and from the California cauliflower industry.

\section{References}

Koike ST, Subbarao KV, Davis RM, Gordon TR. 1996. Verticillium wilt threatens coastal cauliflower crop. Cal Ag 50(2):24-7.

Brown PD, Morra MJ. 1997. Control of soil-borne plant pests using glucosinolatecontaining plants, p. 167-231. In: Sparks DL (ed.). Advances in Agronomy, Vol. 61.

Gamliel A, Stapleton JJ. 1993. Characterization of antifungal volatile compounds evolved from solarized soil amended with cabbage residues. Phytopathology 83:899905.

Harborne JB, Baxter H. 1993. Phytochemical Dictionary: A Handbook of Bioactive Compounds from Plants. Washing- ton, D.C.: Taylor and Francis, Inc. 791 p. Koike ST, Subbarao KV, Davis RM et al. 1994. Verticillium wilt of cauliflower in California. Plant Disease 78:1116-21.

Mayton HS, Olivier C, Vaughn SF, Loria R. 1996. Correlation of fungicidal activity of Brassica species with allyl isothiocyanate production in macerated leaf tissue. Phytopathology 86:267-71.

Mojtahedi H, Santo GS, Hang AN, Wilson JH. 1991. Suppression of root-knot nematode populations with selected rapeseed cultivars as green manure. J. of Nematology 23:170-4.

Subbarao KV. Hubbard JC. 1996. Interactive effects of broccoli residue and temperature on Verticillium dahliae microsclerotia in soil and on wilt in cauliflower. Phytopathology 86:1303-10.

Subbarao KV, Hubbard JC, Koike ST. 1999. Evaluation of broccoli residue incorporation into field soil for Verticillium wilt control in cauliflower. Plant Disease 83:124-9. 